\title{
Fate of cerium dioxide nanoparticles in endothelial cells: exocytosis
}

\author{
Claudia Strobel · Hartmut Oehring • \\ Rudolf Herrmann • Martin Förster • \\ Armin Reller • Ingrid Hilger
}

Received: 25 January 2015/Accepted: 16 April 2015/Published online: 5 May 2015

(C) The Author(s) 2015. This article is published with open access at Springerlink.com

\begin{abstract}
Although cytotoxicity and endocytosis of nanoparticles have been the subject of numerous studies, investigations regarding exocytosis as an important mechanism to reduce intracellular nanoparticle accumulation are rather rare and there is a distinct lack of knowledge. The current study investigated the behavior of human microvascular endothelial cells to exocytose cerium dioxide $\left(\mathrm{CeO}_{2}\right)$ nanoparticles $(18.8 \mathrm{~nm})$ by utilization of specific inhibitors [brefeldin A; nocodazole; methyl- $\beta$-cyclodextrin $(\mathrm{M} \beta \mathrm{cD})]$ and
\end{abstract}

C. Strobel · I. Hilger $(\bowtie)$

Department of Experimental Radiology, Institute of Diagnostic and Interventional Radiology, Jena University Hospital - Friedrich Schiller University Jena, Erlanger Allee 101, 07747 Jena, Germany

e-mail: ingrid.hilger@med.uni-jena.de

C. Strobel

e-mail: Claudia.Strobel@med.uni-jena.de

H. Oehring

Institute of Anatomy II, Jena University Hospital Friedrich Schiller University Jena, Teichgraben 7, 07743 Jena, Germany

R. Herrmann · A. Reller

Department of Physics, University of Augsburg,

Universitaetsstraße 1, 86159 Augsburg, Germany

\section{Förster}

Department of Internal Medicine I, Division of Pulmonary Medicine and Allergy/Immunology, Jena University Hospital - Friedrich Schiller University Jena, Erlanger Allee 101, 07747 Jena, Germany different analytical methods (flow cytometry, transmission electron microscopy, inductively coupled plasma mass spectrometry). Overall, it was found that endothelial cells were able to release $\mathrm{CeO}_{2}$ nanoparticles via exocytosis after the migration of nanoparticle containing endosomes toward the plasma membrane. The exocytosis process occurred mainly by fusion of vesicular membranes with plasma membrane resulting in the discharge of vesicular content to extracellular environment. Nevertheless, it seems to be likely that nanoparticles present in the cytosol could leave the cells in a direct manner. $\mathrm{M} \beta \mathrm{cD}$ treatment led to the strongest inhibition of the nanoparticle exocytosis indicating a significant role of the plasma membrane cholesterol content in the exocytosis process. Brefeldin A (inhibitor of Golgi-to-cell-surface-transport) caused a higher inhibitory effect on exocytosis than nocodazole (inhibitor of microtubules). Thus, the transfer from distal Golgi compartments to the cell surface influenced the exocytosis process of the $\mathrm{CeO}_{2}$ nanoparticles more than the microtubule-associated transport. In conclusion, endothelial cells, which came in contact with nanoparticles, e.g., after intravenously applied nano-based drugs, can regulate their intracellular nanoparticle amount, which is necessary to avoid adverse nanoparticle effects on cells.

Keywords Cerium dioxide $\cdot$ Endothelial cells · Exocytosis - Exocytosis inhibitor - Nanoparticle . Health effects 


\section{Introduction}

The impact of nanotechnology in various branches of industry and in medicine has increased in the last years, which is reflected by nanoparticles' use, for example, in certain products of the food sector (Chaudhry et al. 2008), or for prospective medical applications [e.g., for optical imaging (Jiang et al. 2010), for cancer therapy (Hilger 2013; Johannsen et al. 2005), or for drug delivery (Cho et al. 2008)], as contrast agents (Hahn et al. 2011), in cosmetics like sun protection agents (Strobel et al. 2014a) etc. Therefore, humans are increasingly faced with nanoparticles in daily life. The loading of cells with nanoparticles plays an important role for nanoparticles' biocompatibility. In this context, there are many studies dealing with nanoparticles' uptake in cells by endocytosis processes (Chithrani et al. 2006; Kim et al. 2006; Lesniak et al. 2012; Ma et al. 2013; Meng et al. 2011; Treuel et al. 2013). Such studies revealed that nanoparticles' endocytosis is a concentration-, time- and energy-dependent process (Panyam and Labhasetwar 2003) and that it is mediated by clathrin, caveolae, and other mechanisms (Canton and Battaglia 2012). Moreover, it was shown that endocytosis of nanoparticles is dependent on cell type and on nanoparticles' properties, like size, shape, and surface chemistry [(Canton and Battaglia 2012), and reviewed in (Oh and Park 2014)].

However, cell loading with nanoparticles is not only dependent on uptake, but also on time of intracellular retention and therefore on the behavior of cells to excrete internalized nanoparticles. A comprehensive understanding of exocytosis is of relevance for nanotoxicity assessments and for toxicity categorization of nanomaterials. Nevertheless until now exocytosis of nanoparticles has been the subject of only few studies [reviewed in (Oh and Park 2014)]. Examples are exocytosis of silica (Chu et al. 2011; Hu et al. 2011), gold (Bartczak et al. 2012; Chithrani and Chan 2007; Wang et al. 2011), or of polymer nanoparticles (Dombu et al. 2010; He et al. 2013a, b; Panyam and Labhasetwar 2003) in several tumor and non-tumor cell lines. Based on theses studies, it seems that exocytosis is a dynamic and energy-dependent process (Panyam and Labhasetwar 2003) like endocytosis. It is dependent on cell type (Chithrani and Chan 2007; Chu et al. 2011; Wang et al. 2011), nanoparticle amount in supernatants (Chu et al. 2011), and the nanoparticles' properties like size
(Chithrani and Chan 2007; Hu et al. 2011), shape (Chithrani and Chan 2007), and functionalization (Bartczak et al. 2012). Some studies demonstrated an involvement of cell membrane cholesterol (Dombu et al. 2010) and of intracellular membrane transport in exocytosis processes ( $\mathrm{He}$ et al. 2013a, b).

Interestingly, cerium dioxide $\left(\mathrm{CeO}_{2}\right)$ nanoparticles have been suggested to be included in cosmetics as UV filters and ROS scavengers (Boutard et al. 2013; Truffault et al. 2012; Yabe and Sato 2003) or in drugs for the treatment of medical disorders (Chigurupati et al. 2013; Karakoti et al. 2008; Niu et al. 2007; Schubert et al. 2006; Silva 2006). Therefore, a direct exposure of $\mathrm{CeO}_{2}$ nanoparticles with endothelial cells will occur, particularly if $\mathrm{CeO}_{2}$ nanoparticles will be used in intravenously applied medications. Moreover, $\mathrm{CeO}_{2}$ nanoparticles are present in the air due to their utilization in automobile catalytic converters (Zheng et al. 2005) and as automotive fuel additives (Jung et al. 2005; Park et al. 2008). It was shown that $\mathrm{CeO}_{2}$ nanoparticles were taken up by endothelial cells and were located perinuclearly (Strobel et al. 2014b), but it is unclear whether they can be exocytosed from cells.

Therefore, the objective of the present study was to determine the behavior of endothelial cells to exocytose $\mathrm{CeO}_{2}$ nanoparticles and we asked the following questions: (1) if nanoparticle intracellular accumulation decreases with increasing time after exposure, (2) which amounts of nanoparticles are detectable in the cell supernatants as a general measure of exocytosis with increasing time after exposure, (3) if nanoparticles are re-arranged within cells after nanoparticle exposure, and (4) which cellular components are involved in the exocytosis processes.

\section{Materials and methods}

Synthesis of the nanoparticles

Reagents and solvents of synthesis were obtained from Merck KGaA and Sigma-Aldrich if not otherwise specified. Ethanol (absolute for analysis) was used throughout the study.

$\mathrm{CeO}_{2}$ nanoparticles were synthesized using the method of Chen and Chang (Chen and Chang 2004, 2005). A solution of cerium(III) nitrate hexahydrate $(3 \mathrm{mmol}, 1.30 \mathrm{~g})$ in $30 \mathrm{ml}$ of water was stirred at $85{ }^{\circ} \mathrm{C}$ (oil bath temperature) in a round-bottom flask, 
and $1.5 \mathrm{ml}$ of aqueous ammonia (25\%) was added. Stirring was continued for $3.5 \mathrm{~h}$ while allowing contact of the solution with air. After cooling to room temperature and stirring for $15 \mathrm{~h}$, the suspension was centrifuged at 6,700 $\mathrm{g}$ for $15 \mathrm{~min}$, and the precipitated nanoparticles were purified by redispersion in water (24 ml) and centrifugation (repeated 3 times), followed by redispersion in ethanol $(24 \mathrm{ml})$ and centrifugation (repeated 3 times). They were stored in ethanol (9 ml). The yield was $340 \mathrm{mg}(51 \%)$ of $\mathrm{CeO}_{2}$ nanoparticles. Before their utilization in experiments, the nanoparticles were redispersed in sterile Millipore water (centrifugation and redispersion in $1.0 \mathrm{ml}$ Millipore water; repeated 4 times), were vortexed and treated with ultrasound (10 min; ultrasound bath Bandelin Sonorex RK $52 \mathrm{H}$, Bandelin electronic GmbH \& Co. KG, Germany; HF-power: $60 \mathrm{~W}_{\text {eff }}$ ).

Unlabeled nanoparticles were analyzed via transmission electron microscopy (TEM) and inductively coupled plasma mass spectrometry (ICP-MS). The flow cytometry analysis was carried out with ATTO 647 N-labeled nanoparticles.

The labeling reagent ATTO 647 N-APS was prepared from commercial ATTO $647 \mathrm{~N}$ NHS ester (Sigma-Aldrich) by reaction with (3-aminopropyl)triethoxysilane (APS). Thus, $0.9 \mu \mathrm{mol}(0.75 \mathrm{mg})$ of the NHS ester was dissolved in $70 \mu \mathrm{l}$ of dimethylformamide and stirred with $2.0 \mathrm{ml}$ of an APS solution $(1 \mathrm{mM})$ in ethanol for $2 \mathrm{~h}$ at room temperature. Completeness of the reaction (formation of the labeling reagent ATTO 647 N-APS) was checked by thin layer chromatography (silica, chloroform/ethanol 2:1, movement along the plate: retardation factor $\left(R_{\mathrm{f}}\right)$ NHS ester $0.7, R_{\mathrm{f}}$ ATTO $647 \mathrm{~N}$-APS 0.8$)$. The solution was diluted with $0.9 \mathrm{ml}$ of ethanol to obtain a $0.32 \mathrm{mM}$ stock solution of the reactive dye species (structure see Fig. 1b), which can be stored at $5{ }^{\circ} \mathrm{C}$ for at least 2 months (data not shown).

The stability of the label at room temperature in endothelial cell culture medium was checked by monitoring the fluorescence spectra on storage in the dark. To $3.0 \mathrm{ml}$ of the medium, $20 \mu \mathrm{l}$ of the ATTO 647 N-APS stock solution was added, mixed by shaking and then measured directly (excitation $640 \mathrm{~nm}$, maximum emission at $660 \mathrm{~nm}$; F900 luminescence spectrometer; Edinburgh Analytical Instruments, UK) at the time points shown in Fig. 1c.

The $\mathrm{CeO}_{2}$ nanoparticles (100 mg) were dispersed in ethanol $(3 \mathrm{ml})$ in a $4-\mathrm{ml}$ glass vial with screw cap and Teflon gasket (Wheaton). After addition of $150 \mu \mathrm{l}$ of the ATTO $647 \mathrm{~N}$-APS stock solution, the tightly closed vial was stirred at $120{ }^{\circ} \mathrm{C}$ (oil bath temperature) for $3 \mathrm{~h}$. The label was covalently bonded to the nanoparticle surface by a transesterification reaction of the triethoxysilyl group with hydroxy groups on the $\mathrm{CeO}_{2}$ surface. The particles were isolated by centrifugation $(11,000 \mathrm{~g} ; 15 \mathrm{~min})$. Unreacted ATTO $647 \mathrm{~N}$ APS was removed by redispersion/centrifugation with ethanol ( $6 \mathrm{ml}, 5$ repetitions). The particles were stored in ethanol. Fluorescence spectra in ethanol dispersion showed appreciable labeling.

\section{Nanoparticle characterization}

To characterize the used nanoparticles, the shape and size were determined by TEM (JEM $2100 \mathrm{~F}$ instrument; Jeol, Tokyo, Japan). The samples were prepared by spreading ethanol dispersions of the nanoparticles on a carbon film supported on a 200-mesh copper grid (Plano GmbH) and drying in air. TEM pictures of the nanoparticles were analyzed with the program ImageJ (http://rsb.info.nih.gov/ij/). The diameter of the circumscribed sphere for all nanoparticles was measured to obtain their average size due to their different morphologies.

The hydrodynamic diameters and the $\zeta$-potentials of $\mathrm{CeO}_{2}$ nanoparticles $(50 \mu \mathrm{g} / \mathrm{ml})$ in water and cell culture medium $\left(\right.$ Gibco $^{\circledR}$ MCDB 131 medium (Life Technologies GmbH, Germany), $10 \%$ (v/v) fetal bovine serum (FBS; Life Technologies GmbH, Germany), $1 \%$ (v/v) GlutaMAX ${ }^{\mathrm{TM}}$ I 100X (Life Technologies $\mathrm{GmbH}$, Germany), $1 \mu \mathrm{g} / \mathrm{ml}$ hydrocortisone (Sigma-Aldrich Chemie GmbH, Germany), $10 \mathrm{ng} / \mathrm{ml}$ epidermal growth factor (Life Technologies $\mathrm{GmbH}$, Germany)) were measured using a zetasizer apparatus (Nano ZS Malvern Instruments, UK).

The cytotoxicity of similar $\mathrm{CeO}_{2}$ nanoparticles was investigated in a previous investigation (Strobel et al. 2014b) showing that the used nanoparticle concentrations of the present study did not affect the cells adversely.

\section{Cell cultures}

Immortalized human microvascular endothelial cells (HMEC-1; Centers for Disease Control and Prevention, USA) were grown in cell culture medium $\left(\right.$ Gibco $^{\circledR}$ MCDB 131 medium (Life Technologies 
a

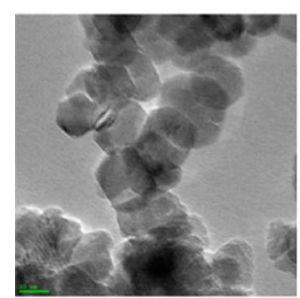

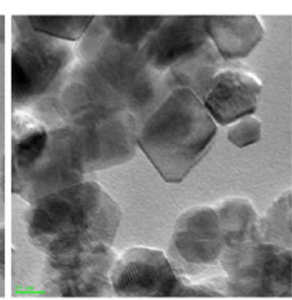

b

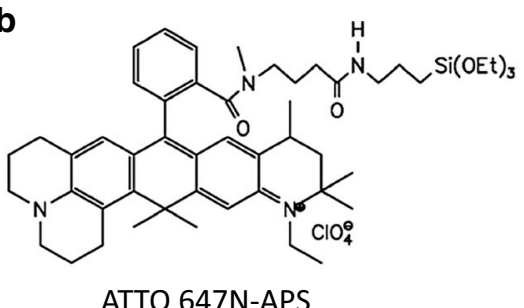

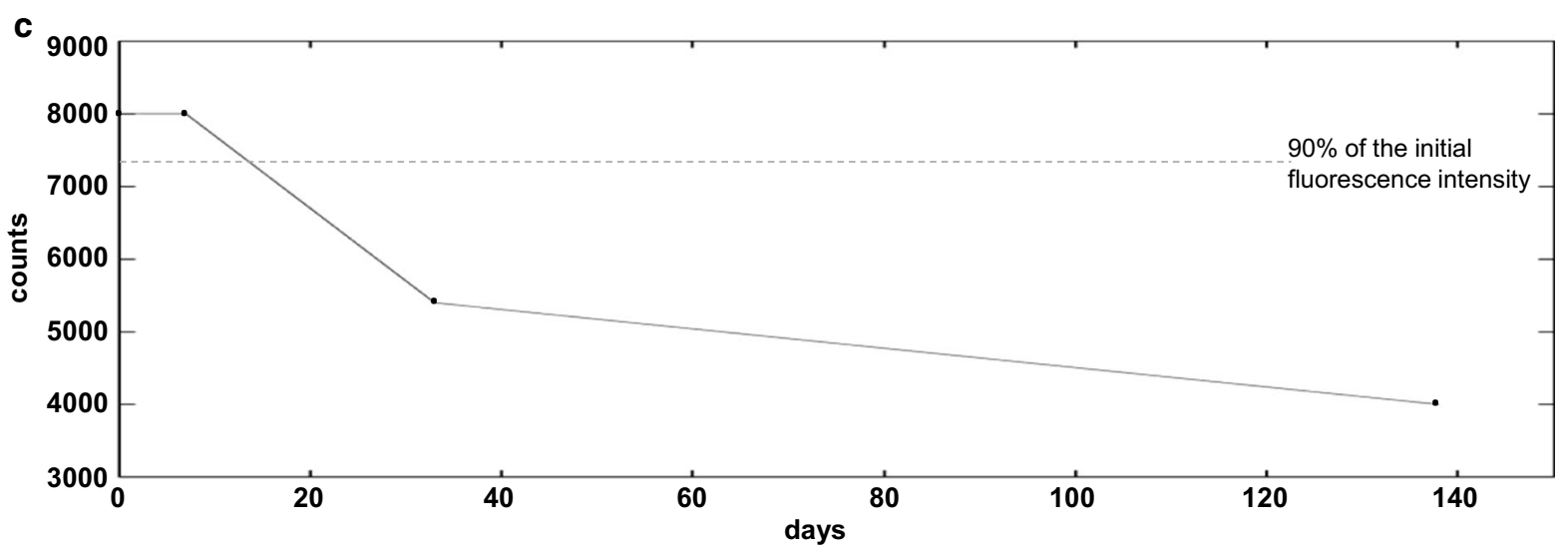

Fig. 1 Nanoparticles' features. a TEM pictures of the $\mathrm{CeO}_{2}$ nanoparticles show the varying shapes. b Structure of the reactive dye species ATTO $647 \mathrm{~N}$-APS used for labeling. c Stability test of the ATTO 647 N-APS label in endothelial cell

GmbH, Germany), $10 \%$ (v/v) FBS (Life Technologies $\mathrm{GmbH}$, Germany), $1 \%(\mathrm{v} / \mathrm{v})$ GlutaMAX $^{\mathrm{TM}} \mathrm{I}$ 100X (Life Technologies GmbH, Germany), $1 \mu \mathrm{g} / \mathrm{ml}$ hydrocortisone (Sigma-Aldrich Chemie GmbH, Germany), $10 \mathrm{ng} / \mathrm{ml}$ epidermal growth factor (Life Technologies $\mathrm{GmbH}$, Germany)) in a humidified incubator at $37{ }^{\circ} \mathrm{C}$ in a $5 \% \mathrm{CO}_{2}$ atmosphere by changing the cell culture medium every 2-3 days. Cell cultures were subcultivated until reaching 70-85\% confluence using GIBCO $^{\circledR}$ trypsin (Life Technologies GmbH, Germany) and were free of mycoplasma as it was regularly tested by PCR.

Investigation of exocytosis via flow cytometry

HMEC-1 were incubated with $1 \mu \mathrm{g} / \mathrm{ml} \mathrm{CeO}_{2}$-ATTO $647 \mathrm{~N}$ for $24 \mathrm{~h}$. Then the cells were washed with Hank's BSS (Biochrom AG, Germany) and fresh nanoparticle-free medium was added. After several time points, the cells were measured via flow cytometry $[10,000$ cells; FACS Calibur (BectonDickinson $\mathrm{GmbH}$, Germany); $635 \mathrm{~nm}$ laser; filter: culture medium (PAA Laboratories, Pasching, Austria) revealed the stability of the dye for at least 2 weeks, since $90-95 \%$ of the initial fluorescence intensity of the ATTO 647 N-APS label was present after this period

FI4 661/16; CellQuest Pro ${ }^{\mathrm{TM}}$ software (BectonDickinson GmbH, Germany)]. For the long time follow-up (up to 240-h follow-up time), the median fluorescence intensity (MFI) of the appropriate untreated cell population was subtracted from the MFI of nanoparticle-exposed cells and the ratio of MFI of follow-up ("48 h"-“240 h") to initial value ("0 h" follow-up; cells which were exposed to $\mathrm{CeO}_{2}$ nanoparticles for $24 \mathrm{~h}$ ) was calculated.

To study the role of cellular constituents in exocytosis of nanoparticles, different inhibitors were used which affected different cellular structures/components. After the $24 \mathrm{~h}$ nanoparticle internalization, the cells were washed and exposed either to fresh nanoparticle-free medium, to Brefeldin A Ready Made Solution $(0.1 \mu \mathrm{g} / \mathrm{ml}$ for $24 \mathrm{~h}$; Sigma-Aldrich Chemie $\mathrm{GmbH}$, Germany), to InSolution ${ }^{\mathrm{TM}}$ Nocodazole $(10 \mu \mathrm{g} / \mathrm{ml}$ for $24 \mathrm{~h}$; Merck KGaA, Germany), or to methyl- $\beta$-cyclodextrin $(\mathrm{M} \beta \mathrm{cD})(10 \mathrm{mM}$ for 2 or $1 \mathrm{~h}$, follow-up: 22 or $23 \mathrm{~h}$, respectively; Sigma-Aldrich Chemie $\mathrm{GmbH}$, Germany). $24 \mathrm{~h}$ after addition of fresh medium or inhibitor, 10,000 cells were analyzed via flow 
cytometry (FACS Calibur (Becton-Dickinson GmbH, Germany); 635 nm laser; filter: FI4 661/16; CellQuest Pro $^{\text {TM }}$ software (Becton-Dickinson GmbH, Germany)). The exocytosis rate of each sample was calculated using the MFI: The MFI of the appropriate control cell population was subtracted from the MFI of corresponding nanoparticle exposed cells. The percentile ratio of MFI of follow-up (" $24 \mathrm{~h}$ " follow-up after washing and medium exchange) to initial value ("0 h" follow-up; cells which were exposed to $\mathrm{CeO}_{2}$ nanoparticles for $24 \mathrm{~h}$ ) was calculated and subtracted from $100 \%$, resulting in the exocytosis rate.

Investigation of exocytosis via TEM

HMEC-1 were seeded in 12-well plates and incubated with $10 \mu \mathrm{g} / \mathrm{ml}$ of $\mathrm{CeO}_{2}$ nanoparticles for $24 \mathrm{~h}$. To investigate the exocytosis of the nanoparticles, $24 \mathrm{~h}$ after nanoparticle treatment the cells were washed and a cell culture medium exchange followed to remove the non-internalized nanoparticles. To inhibit the exocytosis of certain samples, cells were treated either with Brefeldin A Ready Made Solution $(0.1 \mu \mathrm{g} / \mathrm{ml}$ for $24 \mathrm{~h}$; Sigma-Aldrich Chemie GmbH, Germany), with InSolution $^{\mathrm{TM}}$ Nocodazole $(10 \mu \mathrm{g} / \mathrm{ml}$ for $24 \mathrm{~h}$; Merck $\mathrm{KGaA}$, Germany), or with $\mathrm{M} \beta \mathrm{cD}(10 \mathrm{mM}$ for $2 \mathrm{~h}$, follow-up: 22 h; Sigma-Aldrich Chemie GmbH, Germany) in cell culture medium. $24 \mathrm{~h}$ after medium exchange, the cells were washed with Hank's BSS (Biochrom AG, Germany) and fixed for $30 \mathrm{~min}$ at $20{ }^{\circ} \mathrm{C}$ with $2 \%$ glutaraldehyde solution in $0.1 \mathrm{M}$ cacodylate buffer ( $\mathrm{pH} 7.4,5 \%$ sucrose). After repeated rinsing in $0.1 \mathrm{M}$ cacodylate buffer $(\mathrm{pH} \mathrm{7.4,} 6.8 \%$ sucrose), specimen was postfixed with a freshly prepared mixture of $2 \%$ osmiumtetroxide (in distilled water) and $3 \%$ potassium ferrocyanide $(0.2 \mathrm{M}$ cacodylate, $\mathrm{pH} 7.4$ ) for $2 \mathrm{~h}$ at $4{ }^{\circ} \mathrm{C}$ followed by thorough washing in $0.1 \mathrm{M}$ cacodylate buffer $(\mathrm{pH}$ 7.4) until the solution remained clear. Tissue sample was dehydrated in graded ethanol series and embedded in Epon 812 (FERAK, Berlin, Germany) via acetonitrile as inter medium. Samples were polymerized at $60^{\circ} \mathrm{C}$ for 7 days. Ultrathin sections prepared with low-angle diamond knives were mounted on formvar-coated copper rhodium grids and stained with $1 \%$ uranylacetate (in methanol) and freshly prepared lead citrate (25 mg/10 ml distilled water). Sections were examined by an EM 902A (ZEISS, Oberkochen, Germany) operating with an accelerating voltage of $80 \mathrm{kV}$.
Investigation of exocytosis via ICP-MS

HMEC-1 were treated with $100 \mu \mathrm{g} / \mathrm{ml} \mathrm{CeO}_{2}$ nanoparticles to be above the detection limit of the method. After $24 \mathrm{~h}$ of nanoparticle exposure, the cells were washed and nanoparticle-free cell culture medium was added to the cells either with or without $\mathrm{M} \beta \mathrm{cD}$ (10 $\mathrm{mM}$ for $2 \mathrm{~h}$, follow-up: $22 \mathrm{~h}$; Sigma-Aldrich Chemie GmbH, Germany). After appropriate incubation time, the cell culture supernatant was collected. $7 \mathrm{ml} \mathrm{HNO}{ }_{3}\left(\mathrm{HNO}_{3} 65 \%\right.$; Merck, cleaned by subboiling distillation) was added to $1 \mathrm{ml}$ of each cell culture supernatant and a microwave-assisted digestion (Mars 5Xpress, CEM) followed. The cell culture supernatant samples were filled up to a final volume of $25 \mathrm{ml}$ with deionized water (GenPure UV-TOC, Fisher Scientific). The concentration of cerium $(\mathrm{Ce})$ in the appropriate digestion solution was determined via ICP-MS (XSeriesII, Thermo Fisher Scientific). For each sample, three measurements were done.

\section{Statistical analysis}

During data analysis, the mean values and the standard deviations were calculated. Statistical data evaluation was carried out via ANOVA and post hoc Bonferroni test using IBM SPSS Statistics (version 22.0, Inc, IBM Company, USA). Data were stated as statistically significant if $P \leq 0.05$.

\section{Results}

$\mathrm{CeO}_{2}$ nanoparticle characterization

The morphology of the used nanoparticles varied from octahedral to spherical (Fig. 1a; Table 1) with an average size of $18.8 \pm 4.5 \mathrm{~nm}$ (Table 1). The degree of clustering varied over a large range, but it could not be quantified from TEM pictures. Dynamic light scattering (DLS) measurements suggested a strong clustering behavior of nanoparticles in the presence of cell culture medium (Table 1). The $\zeta$-potential of nanoparticles changed from positive to negative when the nanoparticles were suspended in FBS-containing cell culture medium $(10 \%)$ indicating the occurrence of protein adsorption on the nanoparticles' surface (Table 1). Unlabeled and labeled nanoparticles revealed similar properties (Table 1). Therefore, 
Table 1 Characterization of the used $\mathrm{CeO}_{2}$ nanoparticles regarding shape, size, and $\zeta$-potential

\begin{tabular}{|c|c|c|}
\hline & With ATTO dye ${ }^{d}$ & Without ATTO dye $\mathrm{e}^{\mathrm{e}}$ \\
\hline Shape & Octahedral/spheres & Octahedral/spheres \\
\hline Size $(\mathrm{nm})^{\mathrm{a}}$ & $18.8 \pm 4.5$ & $18.8 \pm 4.5$ \\
\hline Size in $\mathrm{H}_{2} \mathrm{O}(\mathrm{nm})^{\mathrm{b}}$ & $65 \pm 1$ & $79 \pm 1$ \\
\hline Size in cell culture medium $(\mathrm{nm})$ shortly after preparation ${ }^{\mathrm{b}, \mathrm{c}}$ & $309 \pm 9$ & $369 \pm 16$ \\
\hline Size in cell culture medium $(\mathrm{nm})$ after $3 \mathrm{~h}$ incubation ${ }^{\mathrm{b}, \mathrm{c}}$ & $307 \pm 1$ & $352 \pm 6$ \\
\hline$\zeta$-potential in $\mathrm{H}_{2} \mathrm{O}(\mathrm{mV})$ & $18.7 \pm 0.5$ & $18.4 \pm 1.0$ \\
\hline$\zeta$-potential in cell culture medium $(\mathrm{mV})^{\mathrm{c}}$ & $-24.1 \pm 0.3$ & $-23.8 \pm 0.6$ \\
\hline
\end{tabular}

${ }^{a}$ By TEM

b By DLS (polydispersity index $<0.5$ )

c Cell culture medium supplemented with $10 \%$ FBS

d Nanoparticles which were labeled with the dye ATTO 647 N-APS were used in flow cytometry analysis

e Unlabeled counterparts were used for TEM and ICP-MS analysis

nanoparticle labeling should have no distinct effect on their uptake and exocytosis by the target cells.

The labeled nanoparticles were stable for at least two weeks, since $90-95 \%$ of the initial fluorescence intensity of the ATTO $647 \mathrm{~N}$-APS label was present after this period of time, as the stability test in cell culture medium showed (Fig. 1c).

Exocytosis of nanoparticles

\section{Decrease of intracellular nanoparticle accumulation and partial re-uptake of exocytosed nanoparticles with increasing time after exposure}

The analysis of the ability of HMEC-1 to exocytose nanoparticles generally showed a continuing reduction in the MFI of the cell population with increasing follow-up time after the cells were treated with nanoparticles (Fig. 2a). For example, cells which were exposed to nanoparticles for $24 \mathrm{~h}$ (correspond to follow-up time point " $0 \mathrm{~h}$ ") and then washed and supplied with fresh nanoparticle free medium, revealed approximately $70 \%$ of the initial MFI value (value at " $0 \mathrm{~h}$ " follow-up) at $48 \mathrm{~h}$ after the medium exchange ("48 h" follow-up time), $35 \%$ after $72 \mathrm{~h}$, only $1.7 \%$ after $120 \mathrm{~h}$, and $0.3 \%$ after $240 \mathrm{~h}$ (Fig. 2a). Since the fluorescence correlated with the internalized nanoparticle amount, this decrease indicated a nanoparticle reduction within the cell population.

The Ce content in the cell culture medium supernatants of cells, which were exposed to $\mathrm{CeO}_{2}$ nanoparticles for $24 \mathrm{~h}$ and then processed as mentioned above, confirmed the exocytosis of intracellular nanoparticles at the different time points (Fig. 2b). The cell culture supernatants of the 48 and 72-h follow-up presented lower Ce concentrations than the $24 \mathrm{~h}$ follow-up samples (Fig. 2b). These findings could be a result of partial re-uptake of already exocytosed nanoparticles in HMEC-1.

\section{Intracellular re-arrangement of nanoparticles with increasing time after exposure and role of cellular constituents in nanoparticle exocytosis}

The investigation of the intracellular localization of nanoparticles with increasing follow-up time after exposure revealed a re-arrangement of the nanoparticles within cells. TEM images of the follow-up time point "0 h" (HMEC-1 were treated with $\mathrm{CeO}_{2}$ nanoparticles for $24 \mathrm{~h}$ ) showed the endocytosis process of the nanoparticles (Fig. 3a). The internalized nanoparticles were found mainly in endosomes (Fig. 3b) and partly in the cytosol (Fig. 3c). At this time point no exocytosis or exocytosis initiation could be observed.

TEM images of HMEC-1, which were firstly treated with nanoparticles for $24 \mathrm{~h}$ and then washed and supplied with fresh nanoparticle free medium, (Fig. 3d-i) disclosed $24 \mathrm{~h}$ after the medium exchange (" $24 \mathrm{~h}$ " follow-up time) a localization of the nanoparticles partly in the cytosol (Fig. 3d) and rarely in lysosomes (Fig. 3e) as well as a migration of the endosomal vesicles with the nanoparticles toward the 

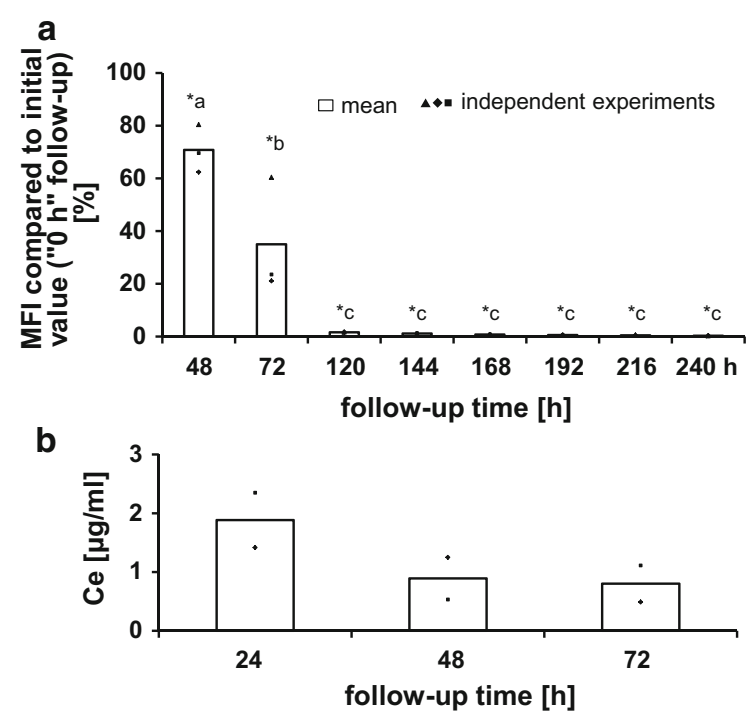

Fig. 2 Decrease of intracellular nanoparticle accumulation and partial re-uptake of exocytosed nanoparticles with increasing time after exposure. a With increasing follow-up time after nanoparticle exposure a continuous decrease of the intracellular fluorescence intensity was observed. This indicates a cellular nanoparticle decrease as result of exocytosis and cell division ("nanoparticle dilution"). $n=3$ independent experiments; $M F I$ median fluorescence intensity of the cell population; asterisks indicate significant differences $(P \leq 0.05)$ to the initial value ("0 h" follow-up; $100 \%$ ), different letters indicate significant differences $(P \leq 0.05)$ between different time points. b The occurrence of cerium $(\mathrm{Ce})$ in the supernatant of endothelial cells, which were previously exposed to $\mathrm{CeO}_{2}$ nanoparticles and which were followed up after washing and cell culture medium exchange (nanoparticle free medium), revealed the occurrence of exocytosis of intracellular nanoparticles. The lower $\mathrm{Ce}$ supernatant concentrations which were found with increasing follow-up time (48 and 72-h follow-up time) in comparison to 24-h follow-up time indicate a re-uptake of exocytosed nanoparticles in cells. The Ce content in supernatants of cells, which were not treated with nanoparticles, was below the detection limit. $n=2$ independent experiments

plasma membrane (Fig. 3e-h). Moreover, the initiation (Fig. 3e, f) and occurrence (Fig. 3h, i) of exocytosis of the internalized nanoparticles were seen clearly. Since hardly no extracellular nanoparticles were observed in TEM images of cells which have been treated with inhibitor (Fig. 3j-1, n, o), the extracellular localization of nanoparticles in relation to non-inhibited cells (Fig. 3h, i) evidences the presence of exocytosis. The exocytosis process seems to occur mainly by fusion of the endosomal membrane with the plasma membrane.
Cells, which were treated after nanoparticle exposure with the inhibitors brefeldin A (Fig. 3j, k; $0.1 \mu \mathrm{g} / \mathrm{ml}$, $24 \mathrm{~h}$ ), nocodazole (Fig. 31, m; $10 \mu \mathrm{g} / \mathrm{ml}, 24 \mathrm{~h}$ ), or $\mathrm{M} \beta \mathrm{cD}$ (Fig. 3n, o; $10 \mathrm{mM}, 2 \mathrm{~h}$ ) to detect the role of cellular constituents in the exocytosis of nanoparticles, presented considerably large nanoparticle-containing endosomes (Fig. 3j, 1, n). This indicated the inhibition of exocytosis. Occasionally, a localization of nanoparticles in secondary lysosomes was detected for brefeldin $A$ and $M \beta c D$-treated cells. In analogy to the native cells (no inhibitor, Fig. 3c), nanoparticles were also found in the cytoplasm of cells additionally exposed to inhibitors (Fig. 3k, m, o). In both cases, the occurrence of nanoparticles in the cytoplasm indicated the presence of endosomal perforation possibly due to a too high amount of nanoparticles which accumulated within the endosomes. Interestingly, it seems that nanoparticles which already translocated to the cytoplasm could be expelled from endothelial cells due to the close vicinity of cytosolic nanoparticles to the plasma membrane in representative TEM images (Fig. 3f, i, m (arrows)). TEM images of nocodazoletreated cells showed a migration of small endosomes containing nanoparticles toward the plasma membrane. It was detected that nocodazole permitted an occasional exocytosis of some single nanoparticles (Fig. $3 \mathrm{~m}$ ), which was hardly the case for brefeldin A or $\mathrm{M} \beta \mathrm{cD}$. Overall, cells treated with one of the three inhibitors showed no or hardly any exocytosis whereby $\mathrm{M} \beta \mathrm{cD}$ showed the best inhibitory effect among all the applied inhibitors.

To quantify the inhibitory effect of each inhibitor, the assessment of the exocytosis rate via flow cytometry analysis was performed (Fig. 4a, b) as described in the experimental section. The optimal nanoparticle concentration for the flow cytometry analysis was $1 \mu \mathrm{g} / \mathrm{ml}$ (exposure time: $24 \mathrm{~h}$ ) as it was demonstrated in a preliminary test (data not shown). Within $24 \mathrm{~h}$ after medium exchange, an average exocytosis rate of $62 \pm 5 \%$ was detected (Fig. 4a). In comparison to the other inhibitors, $\mathrm{M} \beta \mathrm{cD}$ with an exposure time of $2 \mathrm{~h}$ led to the strongest inhibition of nanoparticle exocytosis (exocytosis rate: $22 \pm 3 \%$, Fig. $4 a) . M \beta c D$ with a shorter exposure time $(1 \mathrm{~h})$ led to a weaker inhibition of exocytosis (exocytosis rate: $55 \pm 2 \%$, Fig. 4a) indicating that the cholesterol content of cell membranes played an important role in the exocytosis process. 


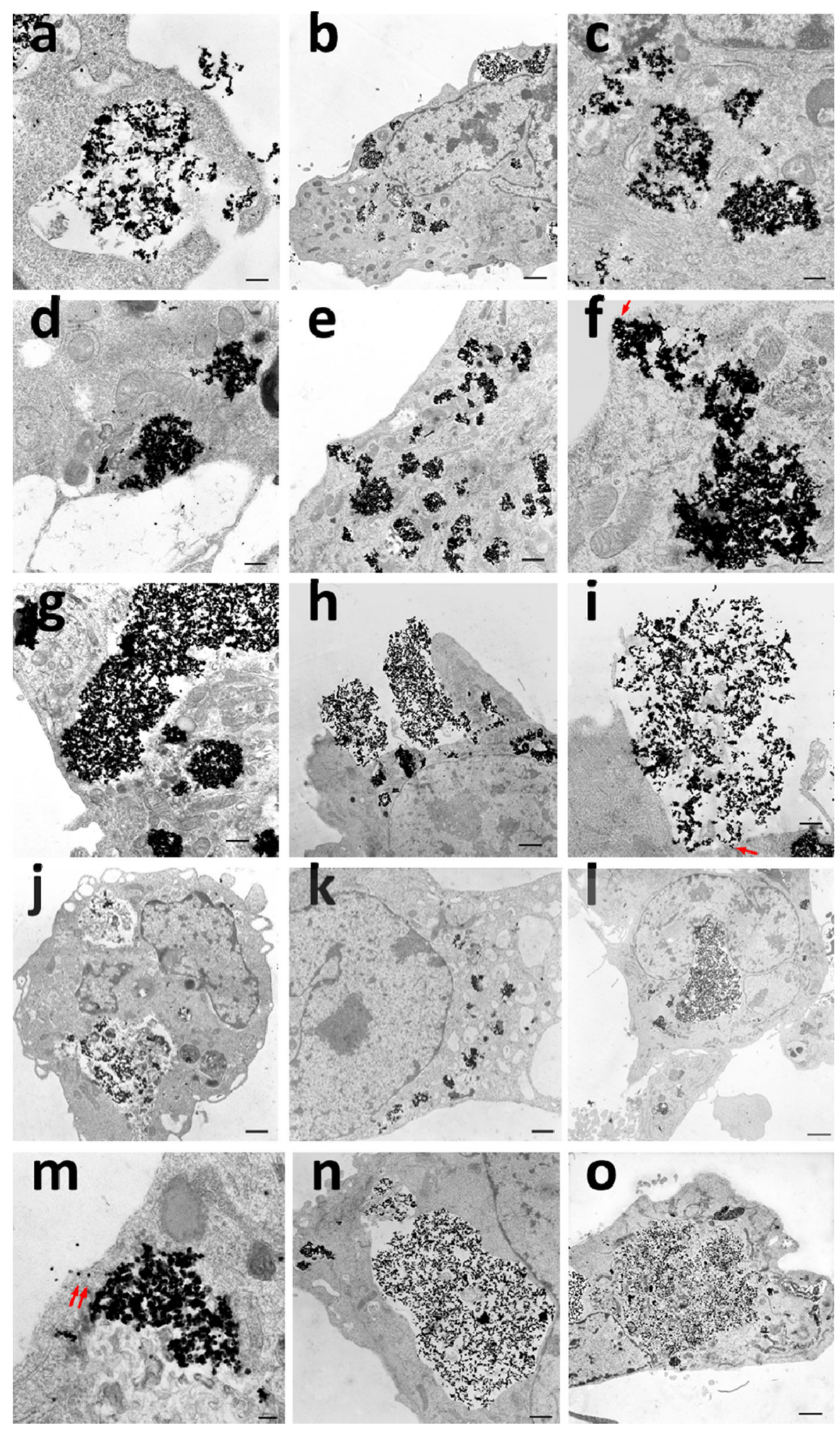


4 Fig. 3 Intracellular localization of nanoparticles with increasing time after exposure and after inhibitor application. TEM images of HEMC-1 after treatment with $10 \mu \mathrm{g} / \mathrm{ml} \mathrm{CeO}_{2}$ nanoparticles for $24 \mathrm{~h}$ show endocytosis (a) and the internalized nanoparticles in endosomes (b) as well as in the cytosol (c). TEM images of the localization of the nanoparticles $24 \mathrm{~h}$ after washing and medium exchange with nanoparticle free medium $(\mathbf{d}-\mathbf{i})$ revealed clearly the initiation $(\mathbf{e}, \mathbf{f})$ and occurrence $(\mathbf{h}, \mathbf{i})$ of exocytosis of the internalized nanoparticles. Cells treated with brefeldin A (j, k; $0.1 \mu \mathrm{g} / \mathrm{ml}, 24 \mathrm{~h})$, nocodazole $(\mathbf{l}, \mathbf{m} ; 10 \mu \mathrm{g} / \mathrm{ml}$, $24 \mathrm{~h})$, or $\mathrm{M} \beta \mathrm{cD}(\mathbf{n}, \mathbf{o} ; 10 \mathrm{mM}, 2 \mathrm{~h})$ revealed no or hardly any exocytosis $(\mathbf{m})$, but the localization of nanoparticles in large endosomes $(\mathbf{j}, \mathbf{l}, \mathbf{n})$ or in the cytoplasm $(\mathbf{k}, \mathbf{m}, \mathbf{o})$. The occurrence of nanoparticles in the cytoplasm indicated endosomal perforation. Arrows $(\mathbf{f}, \mathbf{i}, \mathbf{m})$ point to the cytosolic nanoparticles which are shortly before exocytosis. Scale bars: 0.1 (m); $0.3 \mu \mathrm{m}$ $(\mathbf{b}, \mathbf{c}, \mathbf{d}, \mathbf{f}) ; 0.5 \mu \mathrm{m}(\mathbf{i}) ; 1.0 \mu \mathrm{m}(\mathbf{e}, \mathbf{g}, \mathbf{j}, \mathbf{k}, \mathbf{n}) ; 1.5 \mu \mathrm{m}(\mathbf{a}, \mathbf{h}) ; 2.0(\mathbf{l}$, o)

As a consequence of brefeldin A treatment, an exocytosis rate of $43 \pm 3 \%$ was found, which means that an inhibition of nanoparticle exocytosis occurred (Fig. 4a). The applied inhibitor nocodazole caused no obvious inhibition of nanoparticle exocytosis (exocytosis rate: $59 \pm 2 \%$, Fig. $4 \mathrm{a}$ ). Thus, the transfer from distal Golgi compartments to the cell surface influenced the exocytosis process of the $\mathrm{CeO}_{2}$ nanoparticles to a higher extent than the microtubule-associated transport.

The detected $\mathrm{Ce}$ concentration in cell culture medium supernatants of cells, which were washed and supplied with fresh nanoparticle free cell culture medium after nanoparticle exposure, in comparison to those of cells, which were additionally treated with the inhibitor $\mathrm{M} \beta \mathrm{cD}$, confirmed the inhibitory effect of $\mathrm{M} \beta \mathrm{cD}$ in the exocytosis of $\mathrm{CeO}_{2}$ nanoparticles (Fig. 4c).

\section{Discussion}

Our study has yielded the following results: (1) Endothelial cells are able to release $\mathrm{CeO}_{2}$ nanoparticles via exocytosis to reduce the intracellular nanoparticle accumulation. (2) A partly re-uptake of the already released nanoparticles occurs. (3) After uptake the nanoparticles were mainly localized in endosomes, which migrated toward the plasma membrane and released the nanoparticles in the extracellular environment via membrane fusion. The nanoparticles were partly found in the cytosol and rarely in lysosomes.
Apart from their release via fusion of vesicles with the plasma membrane, nanoparticles seem to also be able to directly leave the cells. (4) The cholesterol content of the cell membrane plays an important role in the exocytosis process. The transfer from distal Golgi compartments to the cell surface influenced the exocytosis process of the $\mathrm{CeO}_{2}$ nanoparticles more than the microtubule-associated transport.

In the present study, flow cytometry analysis showed a reduction of MFI in the cell population with increasing follow-up time after extracellular nanoparticle exposure. This was attributed, at least in part, to exocytosis. However, considering the doubling time of the used HMEC-1 cells (approximately $33.6 \mathrm{~h}$ ), it should be taken into account that the MFI decrease of flow cytometry analysis, besides exocytosis, may result in part also from cell division which can lead to a nanoparticle dilution within the cell population as it was shown by other researches (Errington et al. 2010; Kim et al. 2012; Summers et al. 2011). It is discussed that the distribution of nanoparticles during cell division occurs asymmetrically (Errington et al. 2010; Summers et al. 2011) with the aim to inherit the foreign substance mainly by one of the daughter cells in order to ensure survival of the remaining cell population (Summers 2010). This means that the cell population contained cells with a high nanoparticle amount on one side, and on the other cells with low or even no nanoparticles. On account of the influence of cell division on the MFI, it is necessary to use not only flow cytometry analysis for exocytosis studies, but also complementary methods to verify the obtained results. Thus, in this study the exocytosis process was confirmed by TEM, flow cytometry, and ICP-MS analysis in combination with certain inhibitors.

In this context, the occurrence of $\mathrm{Ce}$ in cell culture medium supernatants of cells after several time points after finalization of the nanoparticle exposure confirmed the exocytosis of $\mathrm{CeO}_{2}$ nanoparticles from endothelial cells. It was perceived that with longer follow-up time $(48 \mathrm{~h} ; 72 \mathrm{~h}$ ) the Ce concentrations of the corresponding cell culture supernatants were lower than those related to a $24-\mathrm{h}$ follow-up time. This finding can be explained by a re-uptake of already exocytosed nanoparticles by HMEC-1, because endocytosis and exocytosis seem to be dynamic processes which occur simultaneously and are dependent from the nanoparticle amount outside and inside of cells (Chu et al. 2011). 

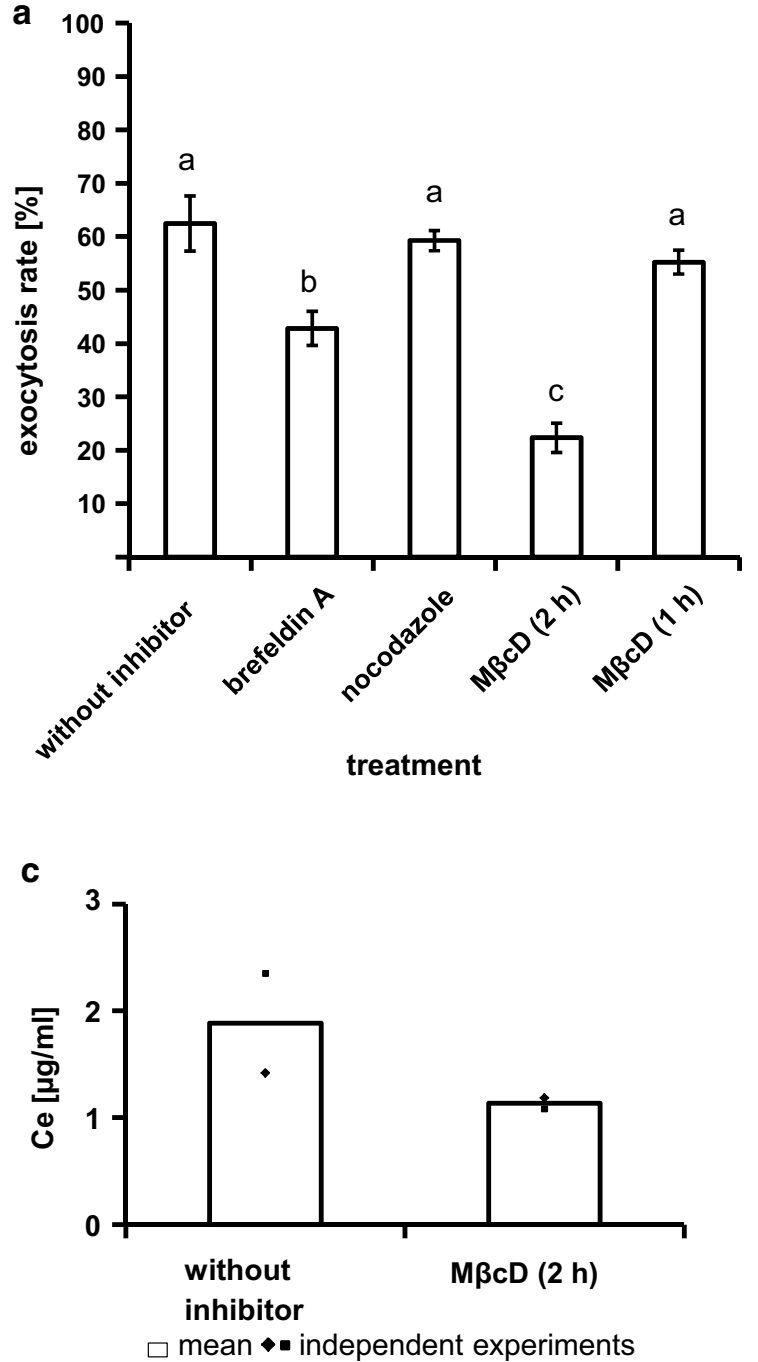

Fig. 4 Strong inhibitory effect of $\mathrm{M} \beta \mathrm{cD}$ and brefeldin $\mathrm{A}$ indicates the important role of plasma membrane cholesterol and Golgi-to-cell-surface-transport, respectively, during nanoparticles exocytosis. a The average exocytosis rate of $\mathrm{CeO}_{2}$ nanoparticles (treatment dose $1 \mu \mathrm{g} / \mathrm{ml}$ for $24 \mathrm{~h}$ ) within $24 \mathrm{~h}$ was $62 \pm 5 \%$. Nocodazole led to no obvious inhibition of nanoparticle exocytosis (exocytosis rate: $59 \pm 2 \%$ ). The highest inhibition of exocytosis was caused by $\mathrm{M} \beta \mathrm{cD}$ with an exposure time of $2 \mathrm{~h}$ indicating an important role of plasma membrane cholesterol for exocytosis. Brefeldin A treatment resulted also in an inhibition of exocytosis revealing an involvement of Golgi-to-cell-surface-transport in exocytosis process. Different letters indicate significant differences

\section{b \\ initial value}
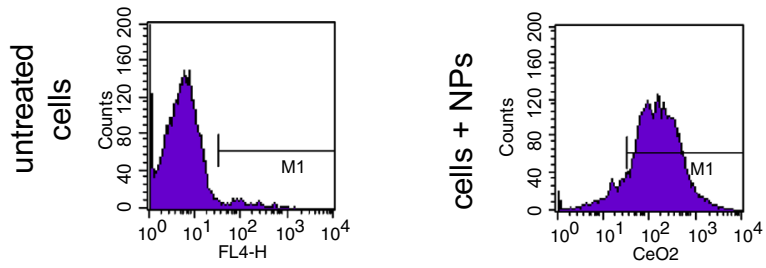

$24 \mathrm{~h}$ post investigation/follow-up
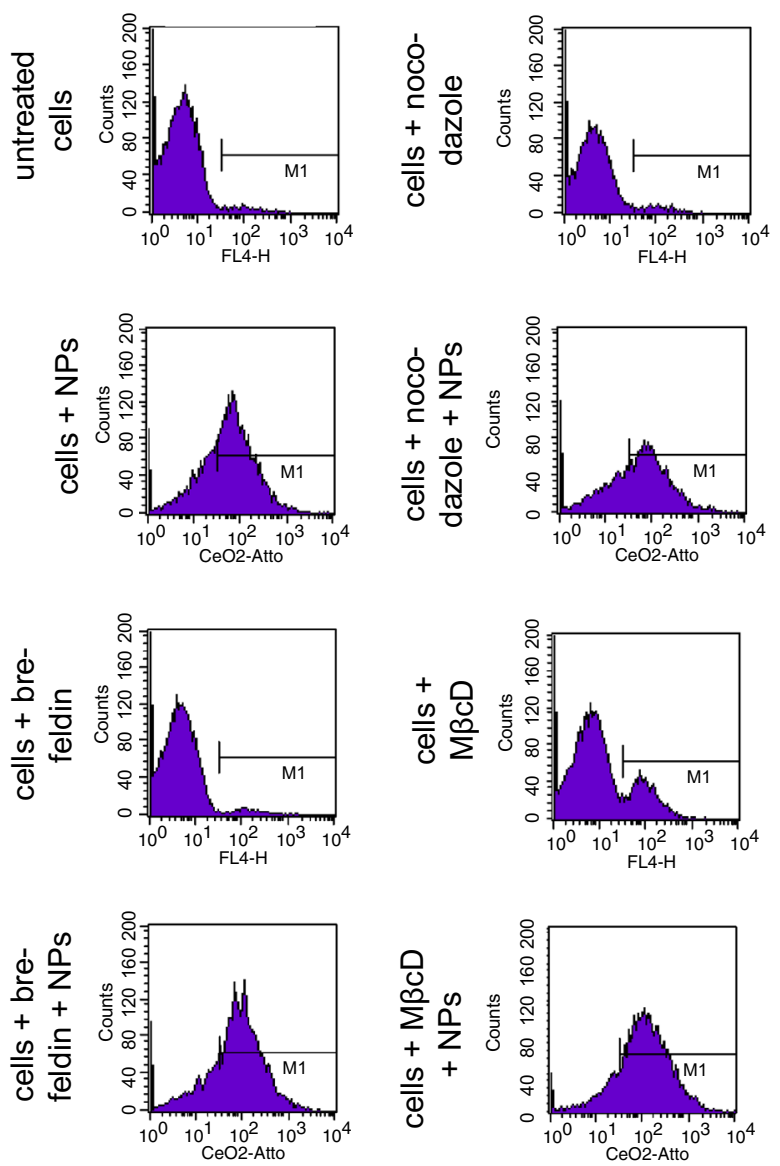

( $P \leq 0.05$ ) between the various treatments. $n \geq 3$ independent experiments; b Histograms of a representative flow cytometry analysis; NPs: nanoparticles. c The determination of cerium (Ce) in the supernatant of HMEC-1, which were exposed to nanoparticles for $24 \mathrm{~h}$, revealed $24 \mathrm{~h}$ after washing and cell culture medium exchange (nanoparticle free medium) a higher amount of $\mathrm{Ce}$ than the supernatants of HMEC-1 which were additionally treated with $\mathrm{M} \beta \mathrm{cD}$-containing cell culture medium after washing and medium exchange. This confirmed the inhibition of exocytosis by $\mathrm{M} \beta \mathrm{cD}$. The $\mathrm{Ce}$ content in supernatants of cells, which were not treated with nanoparticles, was below the detection limit. $n=2$ independent experiments 
TEM analysis indicated that the exocytosis process occurred mainly via fusion of vesicular (especially endosomal) membranes with the plasma membrane, leading to the release of the vesicular content into the extracellular environment. But also a further exocytosis way was detected: The rupture of endosomes which contained nanoparticles (perhaps due to the high amount of internalized nanoparticles) led to the translocation of released nanoparticles to the cytoplasm and from there the nanoparticles seemed to be expelled directly from endothelial cells presumably via unspecific mechanisms.

The application of the different inhibitors clarified, which intracellular pathways are important for exocytosis. In this context, after treatment of cells with $\mathrm{M} \beta \mathrm{cD}$ a strong inhibitory effect on exocytosis was observed via TEM (very large endosomes of cells with $\mathrm{M} \beta \mathrm{cD}$ treatment and hardly no fusion of vesicles containing nanoparticles with the plasma membrane), flow cytometry (lower exocytosis rate of $\mathrm{M} \beta \mathrm{cD}$ treated cells in comparison to non-treated cells), and ICP-MS analysis (lower Ce concentrations in cell culture medium supernatants of cells treated with $\mathrm{M} \beta \mathrm{cD}$ in comparison to non-treated cells). $\mathrm{M} \beta \mathrm{cD}$, a cyclic oligosaccharide, consists of 7 glycopyranose units, which form a hydrophobic cavity, where cholesterol will be incorporated (Pitha et al. 1988) and making it soluble in the aqueous cell culture medium (Klein et al. 1995; Ohtani et al. 1989). M $\beta \mathrm{cD}$ removes the cholesterol selectively from the cell plasma membrane without membrane incorporation (Klein et al. 1995; Ohtani et al. 1989). Thus, the inhibitory effect of $\mathrm{M} \beta \mathrm{cD}$ on exocytosis of $\mathrm{CeO}_{2}$ nanoparticles from endothelial cells indicated a significant role of cholesterol for nanoparticle exocytosis. A shorter incubation time with $\mathrm{M} \beta \mathrm{cD}$ resulted in a much lower inhibition of exocytosis, most likely due to an insufficient reduction in the cell membrane cholesterol content. This finding emphasizes the importance of cell membrane cholesterol for exocytosis processes. Interestingly, the detected inhibitory effect of cholesterol depletion on $\mathrm{CeO}_{2}$ nanoparticle exocytosis from endothelial cells is concordant with findings related to maltodextrin nanoparticles ( $\phi \approx 60 \mathrm{~nm}$ by laser light scattering) exposed to airway epithelium cells (Dombu et al. 2010), but in contrast to published data regarding polymer nanoparticles $(\phi \approx 80 \mathrm{~nm}$ by DLS) and MDCK (He et al. 2013a) or Caco-2 epithelial cells (He et al. 2013b), where the extraction of cholesterol improved exocytosis. This indicates a nanoparticle and/or cell type dependency of nanoparticle exocytosis pathways. A study comparing the ability of three different cell types (lung carcinoma (A549), bronchial epithelial (16HBE), and primary adult stem cells (MSC)) to exclude gold nanorods within $72 \mathrm{~h}$ from the cells reported that only the stem cells excreted the internalized nanoparticles (Wang et al. 2011), which also suggests a cell type dependency in nanoparticle exocytosis. Cell type-specific differences [human esophageal epithelial cells (NE083) and human lung carcinoma cells (H1299)] were also observed in the exocytosis of silica nanoparticles (Chu et al. 2011).

Brefeldin A treatment also caused an inhibitory effect on nanoparticle exocytosis, but to a lesser extent than $\mathrm{M} \beta \mathrm{cD}$. TEM images of nocodazole exposed cells revealed an occasional exocytosis of some single nanoparticles, but overall this was very low in comparison to the exocytosis process of non-treated cells. The contradictory findings between flow cytometry and TEM analysis in relation to nocodazole coincubation of cells (flow cytometry: ineffectiveness of inhibition, quantitative analysis; TEM: only rarely exocytosis; snap-shot analysis) emphasize the importance to verify the exocytosis results with more than one analysis method. Overall, the results regarding brefeldin A and nocodazole suggest that the transfer from distal Golgi compartments to the cell surface [should be inhibited by brefeldin A (Miller et al. 1992)] influences the exocytosis process of the $\mathrm{CeO}_{2}$ nanoparticles more than the microtubule-associated transport [should be inhibited by nocodazole (Peterson and Mitchison 2002)]. The involvement of Golgi to plasma membrane pathway in nanoparticle exocytosis seems to be generally of importance as this pathway was also shown for other nanoparticles (polymer nanoparticles, $\phi \approx 80 \mathrm{~nm}$ by DLS) and cell systems [MDCK and Caco-2 epithelial cells (He et al. 2013a, b)].

On the whole, the present study showed that endothelial cells are able to excrete internalized nanoparticles to control their nanoparticle loading mainly via the plasma membrane cholesterol-dependent mechanisms. While the Golgi to plasma membrane pathway is also important for $\mathrm{CeO}_{2}$ nanoparticle exocytosis, the microtubule-associated transport seems to play only a marginal role. The exocytosis of nanoparticles should be very important for the cell to 
prevent cell damage with the final consequence of cell death as a result of excessive nanoparticle enrichment.

\section{Conclusions}

It can be concluded that endothelial cells, which are the first barrier after nanoparticles arrived at the blood system, are able to remove internalized nanoparticles by exocytosis processes. After uptake, the internalized nanoparticles are re-arranged within cells-the nanoparticle containing vesicles (mainly endosomes) migrates to the plasma membrane. The exocytosis process occurs mainly by fusion of endosomes with the plasma membrane, but probably also-to a less extent-by a direct release of free cytosolic nanoparticles. The already exocytosed nanoparticles can also be re-taken up by cells. An important role of plasma membrane cholesterol was identified for the exocytosis process. Furthermore, the transfer from distal Golgi compartments to the cell surface seems to influence the exocytosis process of the $\mathrm{CeO}_{2}$ nanoparticles more than the microtubule-associated transport. A sufficient exocytosis of nanoparticles should protect endothelial cells for adverse effects of nanoparticle accumulation.

Acknowledgments This research was funded by the German Research Foundation, collaborative project SPP1313, cluster NPBIOMEM, HI-698/11-2. The authors address special thanks to Mr. Dr. D. Merten of the Institute of Geosciences, Applied Geology of the Friedrich Schiller University Jena for the ICPMS analysis and also express gratitude to Mrs. U. Buhler of the Institute of Geosciences, Applied Geology of the Friedrich Schiller University Jena for conducting the microwave-assisted digestion of the ICP-MS analysis. The authors thank Mrs. A. Braunschweig and Mrs. I. Lemke for skillful and excellent technical assistance.

Open Access This article is distributed under the terms of the Creative Commons Attribution 4.0 International License (http:// creativecommons.org/licenses/by/4.0/), which permits unrestricted use, distribution, and reproduction in any medium, provided you give appropriate credit to the original author(s) and the source, provide a link to the Creative Commons license, and indicate if changes were made.

\section{References}

Bartczak D, Nitti S, Millar TM, Kanaras AG (2012) Exocytosis of peptide functionalized gold nanoparticles in endothelial cells. Nanoscale 4(15):4470-4472. doi:10.1039/C2nr31064c
Boutard T, Rousseau B, Couteau C, Tomasoni C, Simonnard C, Jacquot C, Coiffard LJM, Konstantinov K, Devers T, Roussakis C (2013) Comparison of photoprotection efficiency and antiproliferative activity of $\mathrm{ZnO}$ commercial sunscreens and $\mathrm{CeO}_{2}$. Mater Lett 108:13-16. doi:10.1016/ j.matlet.2013.06.085

Canton I, Battaglia G (2012) Endocytosis at the nanoscale. Chem Soc Rev 41(7):2718-2739. doi:10.1039/C2cs15309b

Chaudhry Q, Scotter M, Blackburn J, Ross B, Boxall A, Castle L, Aitken R, Watkins R (2008) Applications and implications of nanotechnologies for the food sector. Food Addit Contam A 25(3):241-258. doi:10.1080/02652030701744538

Chen HI, Chang HY (2004) Homogeneous precipitation of cerium dioxide nanoparticles in alcohol/water mixed solvents. Colloids Surf A 242(1-3):61-69. doi:10.1016/j. colsurfa.2004.04.056

Chen HI, Chang HY (2005) Synthesis of nanocrystalline cerium oxide particles by the precipitation method. Ceram Int 31(6):795-802. doi:10.1016/j.ceramint.2004.09.006

Chigurupati S, Mughal MR, Okun E, Das S, Kumar A, McCaffery M, Seal S, Mattson MP (2013) Effects of cerium oxide nanoparticles on the growth of keratinocytes, fibroblasts and vascular endothelial cells in cutaneous wound healing. Biomaterials 34(9):2194-2201. doi:10. 1016/j.biomaterials.2012.11.061

Chithrani BD, Chan WC (2007) Elucidating the mechanism of cellular uptake and removal of protein-coated gold nanoparticles of different sizes and shapes. Nano Lett 7(6):1542-1550. doi:10.1021/n1070363y

Chithrani BD, Ghazani AA, Chan WCW (2006) Determining the size and shape dependence of gold nanoparticle uptake into mammalian cells. Nano Lett 6(4):662-668. doi:10. $1021 / \mathrm{N} 10523960$

Cho K, Wang X, Nie S, Chen ZG, Shin DM (2008) Therapeutic nanoparticles for drug delivery in cancer. Clin Cancer Res 14(5):1310-1316. doi:10.1158/1078-0432.CCR-07-1441

Chu ZQ, Huang YJ, Tao Q, Li Q (2011) Cellular uptake, evolution, and excretion of silica nanoparticles in human cells. Nanoscale 3(8):3291-3299. doi:10.1039/C1nr10499c

Dombu CY, Kroubi M, Zibouche R, Matran R, Betbeder D (2010) Characterization of endocytosis and exocytosis of cationic nanoparticles in airway epithelium cells. Nanotechnology 21:355102. doi:10.1088/0957-4484/21/35/355102

Errington RJ, Brown MR, Silvestre OF, Njoh KL, Chappell SC, Khan IA, Rees P, Wilks SP, Smith PJ, Summers HD (2010) Single cell nanoparticle tracking to model cell cycle dynamics and compartmental inheritance. Cell Cycle 9(1):121-130. doi:10.4161/Cc.9.1.10246

Hahn MA, Singh AK, Sharma P, Brown SC, Moudgil BM (2011) Nanoparticles as contrast agents for in vivo bioimaging: current status and future perspectives. Anal Bioanal Chem 399(1):3-27. doi:10.1007/s00216-0104207-5

He B, Jia ZR, Du WW, Yu C, Fan YC, Dai WB, Yuan L, Zhang H, Wang XQ, Wang JC, Zhang X, Zhang Q (2013a) The transport pathways of polymer nanoparticles in MDCK epithelial cells. Biomaterials 34(17):4309-4326. doi:10. 1016/j.biomaterials.2013.01.100

He B, Lin P, Jia ZR, Du WW, Qu W, Yuan L, Dai WB, Zhang H, Wang XQ, Wang JC, Zhang X, Zhang Q (2013b) The transport mechanisms of polymer nanoparticles in Caco-2 
epithelial cells. Biomaterials 34(25):6082-6098. doi:10. 1016/j.biomaterials.2013.04.053

Hilger I (2013) In vivo applications of magnetic nanoparticle hyperthermia. Int J Hyperth 29(8):828-834. doi:10.3109/ 02656736.2013.832815

Hu L, Mao Z, Zhang Y, Gao C (2011) Influences of size of silica particles on the cellular endocytosis, exocytosis and cell activity of HepG2 cells. J Nanosci Lett 1(1):1-16

Jiang S, Gnanasammandhan MK, Zhang Y (2010) Optical imaging-guided cancer therapy with fluorescent nanoparticles. J R Soc Interface 7(42):3-18. doi:10.1098/rsif.2009.0243

Johannsen M, Gneveckow U, Eckelt L, Feussner A, Waldöfner N, Scholz R, Deger S, Wust P, Loening SA, Jordan A (2005) Clinical hyperthermia of prostate cancer using magnetic nanoparticles: presentation of a new interstitial technique. Int J Hyperth 21(7):637-647. doi:10.1080/ 02656730500158360

Jung H, Kittelson DB, Zachariah MR (2005) The influence of a cerium additive on ultrafine diesel particle emissions and kinetics of oxidation. Combust Flame 142(3):276-288. doi:10.1016/j.combustflame.2004.11.015

Karakoti AS, Monteiro-Riviere NA, Aggarwal R, Davis JP, Narayan RJ, Self WT, McGinnis J, Seal S (2008) Nanoceria as antioxidant: synthesis and biomedical applications. JomUS 60(3):33-37. doi:10.1007/s11837-008-0029-8

Kim JS, Yoon TJ, Yu KN, Noh MS, Woo M, Kim BG, Lee KH, Sohn BH, Park SB, Lee JK, Cho MH (2006) Cellular uptake of magnetic nanoparticle is mediated through energydependent endocytosis in A549 cells. J Vet Sci 7(4):321-326. doi:10.4142/jvs.2006.7.4.321

Kim JA, Åberg C, Salvati A, Dawson KA (2012) Role of cell cycle on the cellular uptake and dilution of nanoparticles in a cell population. Nat Nanotechnol 7(1):62-68. doi:10. 1038/Nnano.2011.191

Klein U, Gimpl G, Fahrenholz F (1995) Alteration of the myometrial plasma-membrane cholesterol content with betacyclodextrin modulates the binding-affinity of the oxytocin receptor. Biochemistry 34(42):13784-13793. doi:10.1021/ Bi00042a009

Lesniak A, Fenaroli F, Monopoli MP, Åberg C, Dawson KA, Salvati A (2012) Effects of the presence or absence of a protein corona on silica nanoparticle uptake and impact on cells. ACS Nano 6(7):5845-5857. doi:10.1021/nn300223w

Ma N, Ma C, Li C, Wang T, Tang Y, Wang H, Moul X, Chen Z, Hel N (2013) Influence of nanoparticle shape, size, and surface functionalization on cellular uptake. J Nanosci Nanotechnol 13(10):6485-6498. doi:10.1166/jnn.2013.7525

Meng H, Yang S, Li Z, Xia T, Chen J, Ji Z, Zhang H, Wang X, Lin S, Huang C, Zhou ZH, Zink JI, Nel AE (2011) Aspect ratio determines the quantity of mesoporous silica nanoparticle uptake by a small GTPase-dependent macropinocytosis mechanism. ACS Nano 5(6):4434-4447. doi: $10.1021 / \mathrm{nn} 103344 \mathrm{k}$

Miller SG, Carnell L, Moore HPH (1992) Post-golgi membrane traffic-brefeldin-a inhibits export from distal golgi compartments to the cell-surface but not recycling. J Cell Biol 118(2):267-283. doi:10.1083/jcb.118.2.267

Niu JL, Azfer A, Rogers LM, Wang XH, Kolattukudy PE (2007) Cardioprotective effects of cerium oxide nanoparticles in a transgenic murine model of cardiomyopathy. Cardiovasc Res 73(3):549-559. doi:10.1016/j.cardiores.2006.11.031

Oh N, Park JH (2014) Endocytosis and exocytosis of nanoparticles in mammalian cells. Int $\mathrm{J}$ Nanomed 9(Suppl 1):51-63. doi:10.2147/IJN.S26592

Ohtani Y, Irie T, Uekama K, Fukunaga K, Pitha J (1989) Differential-effects of alpha-cyclodextrins, beta-cyclodextrins and gamma-cyclodextrins on human-erythrocytes. Eur $\mathrm{J}$ Biochem 186(1-2):17-22. doi:10.1111/j.1432-1033.1989. tb15171.x

Panyam J, Labhasetwar V (2003) Dynamics of endocytosis and exocytosis of poly(D, L-lactide-co-glycolide) nanoparticles in vascular smooth muscle cells. Pharm Res 20(2):212-220. doi:10.1023/A:1022219003551

Park B, Donaldson K, Duffin R, Tran L, Kelly F, Mudway I, Morin JP, Guest R, Jenkinson P, Samaras Z, Giannouli M, Kouridis H, Martin P (2008) Hazard and risk assessment of a nanoparticulate cerium oxide-based diesel fuel additive-a case study. Inhalation Toxicol 20(6):547-566. doi:10.1080/08958370801915309

Peterson JR, Mitchison TJ (2002) Small molecules, big impact: a history of chemical inhibitors and the cytoskeleton. Chem Biol 9(12):1275-1285. doi:10.1016/S1074-5521(02)00284-3

Pitha J, Irie T, Sklar PB, Nye JS (1988) Drug solubilizers to aid pharmacologists - amorphous cyclodextrin derivatives. Life Sci 43(6):493-502. doi:10.1016/0024-3205(88)90150-6

Schubert D, Dargusch R, Raitano J, Chan SW (2006) Cerium and yttrium oxide nanoparticles are neuroprotective. Biochem Biophys Res Commun 342(1):86-91. doi:10.1016/j. bbrc.2006.01.129

Silva GA (2006) Nanomedicine: seeing the benefits of ceria. Nat Nanotechnol 1(2):92-94. doi:10.1038/nnano.2006.111

Strobel C, Torrano AA, Herrmann R, Malissek M, Bräuchle C, Reller A, Treuel L, Hilger I (2014a) Effects of the physicochemical properties of titanium dioxide nanoparticles, commonly used as sun protection agents, on microvascular endothelial cells. J Nanopart Res 16:2130. doi:10.1007/ s11051-013-2130-3

Strobel C, Förster M, Hilger I (2014b) Biocompatibility of cerium dioxide and silicon dioxide nanoparticles with endothelial cells. Beilstein J Nanotechnol 5:1795-1807. doi:10.3762/bjnano.5.190

Summers H (2010) Can cells reduce nanoparticle toxicity? Nano Today 5(2):83-84. doi:10.1016/j.nantod.2010.01.003

Summers HD, Rees P, Holton MD, Brown MR, Chappell SC, Smith PJ, Errington RJ (2011) Statistical analysis of nanoparticle dosing in a dynamic cellular system. Nat Nanotechnol 6(3):170-174. doi:10.1038/Nnano.2010.277

Treuel L, Jiang XE, Nienhaus GU (2013) New views on cellular uptake and trafficking of manufactured nanoparticles. J R Soc Interface 10:20120939. doi:10.1098/Rsif.2012.0939

Truffault L, Winton B, Choquenet B, Andreazza C, Simmonard C, Devers T, Konstantinov K, Couteau C, Coiffard LJM (2012) Cerium oxide based particles as possible alternative to $\mathrm{ZnO}$ in sunscreens: effect of the synthesis method on the photoprotection results. Mater Lett 68:357-360. doi:10. 1016/j.matlet.2011.10.108

Wang L, Liu Y, Li W, Jiang X, Ji Y, Wu X, Xu L, Qiu Y, Zhao K, Wei T, Li Y, Zhao Y, Chen C (2011) Selective targeting 
of gold nanorods at the mitochondria of cancer cells: implications for cancer therapy. Nano Lett 11(2):772-780. doi:10.1021/nl103992v

Yabe S, Sato T (2003) Cerium oxide for sunscreen cosmetics. J Solid State Chem 171(1-2):7-11. doi:10.1016/S00224596(02)00139-1
Zheng XC, Zhang XL, Wang XY, Wang SR, Wu SH (2005) Preparation and characterization of $\mathrm{CuO} / \mathrm{CeO}_{2}$ catalysts and their applications in low-temperature $\mathrm{CO}$ oxidation. Appl Catal A 295(2):142-149. doi:10.1016/j.apcata.2005.07.048 